\title{
Differential Roles of Hypothalamic AVPV and Arcuate Kisspeptin Neurons in Estradiol Feedback Regulation of Female Reproduction
}

\author{
Luhong Wang $^{\mathrm{a}}$ Suzanne M. Moenter ${ }^{\mathrm{a}-\mathrm{c}}$ \\ ${ }^{a}$ Department of Molecular and Integrative Physiology, University of Michigan, Ann Arbor, MI, USA; ${ }^{b}$ Department \\ of Internal Medicine, University of Michigan, Ann Arbor, MI, USA; ' Department of Obstetrics and Gynecology, \\ University of Michigan, Ann Arbor, MI, USA
}

\section{Keywords}

Ovulation · CRISPR · Estradiol · Reproduction · Kisspeptin ·

Anteroventral periventricular nucleus · Arcuate

\begin{abstract}
Mammalian reproductive function includes puberty onset and completion, reproductive cyclicity, steroidogenesis, gametogenesis, fertilization, pregnancy, and lactation; all are indispensable to perpetuate species. Reproductive cycles are critical for providing the hormonal milieu needed for follicular development and maturation of eggs, but cycles, in and of themselves, do not guarantee ovulation will occur. Here, we review the roles in female reproductive neuroendocrine function of two hypothalamic populations that produce the neuropeptide kisspeptin, demonstrating distinct roles in maintaining cycles and ovulation.
\end{abstract}

(c) 2019 S. Karger AG, Basel

\section{The Reproductive Axis and Estradiol Feedback}

Gonadotropin-releasing hormone $(\mathrm{GnRH})$ neurons integrate central, peripheral, and external cues to generate the central output that regulates fertility $[1,2]$. GnRH neurons reside primarily in the preoptic area (POA) and anterior hypothalamus. These neurons project to the me- dian eminence and release GnRH near the primary capillaries of the hypophyseal portal vasculature, which carry this decapeptide to the pituitary where it activates the synthesis and secretion of the gonadotropins luteinizing hormone (LH) and follicle-stimulating hormone (FSH) $[1,3]$. GnRH is released in an episodic, or pulsatile, manner that is critical for pituitary function [4-6]. High GnRH pulse frequency favors LH synthesis and release, whereas low GnRH pulse frequency preferentially promotes FSH [7-9]. FSH and $\mathrm{LH}$ regulate gametogenesis and steroidogenesis [10]. The sex steroids, including estradiol, progesterone, and testosterone, feed back to the brain to regulate $\mathrm{GnRH}$ release, and on the pituitary to regulate the responsiveness of gonadotropes to $\mathrm{GnRH}$ [11-16]. In males and during most of the female reproductive cycle, sex steroids suppress GnRH neuron activity and release via negative feedback [17-22]. During the preovulatory stage of the female cycle (late follicular phase or proestrus in rodents), a sustained elevation in estradiol causes a switch of estradiol action from negative to positive feedback, thus inducing elevated GnRH neuronal activity and causing a preovulatory surge of $\mathrm{GnRH}$, and subsequent LH, release [6, 23-25]. The LH surge triggers ovulation. There is some debate in higher primates about the necessity of the GnRH surge for ovulation, as an LH surge can occur without a change in episodic release in women [26], and an unchanging frequency of

\section{KARGER}

(c) 2019 S. Karger AG, Basel

E-Mail karger@karger.com

www.karger.com/nen
Suzanne M. Moenter

Department of Molecular and Integrative Physiology, University of Michigan 7725 Med Sci II, 1137 E Catherine St

Ann Arbor, MI 48109-5622 (USA)

E-Mail smoenter@umich.edu 
GnRH pulse administration can induce cycles in monkeys in which endogenous GnRH was ablated [4]. In this regard, it is worth noting that in monkeys, GnRH surges have been observed along with the preovulatory or estradiol-induced LH surge $[27,28]$. In rodents and sheep, a surge release of $\mathrm{GnRH}$ is required for the LH surge [25, 29,30 ]. The investigation of estradiol feedback regulation of the hypothalamus has focused mainly on ovarian estradiol as it is the predominant signal to generate the switch between negative and positive feedback. For a recent review on the possible role of local neurosteroids in these processes, the reader is directed to Terasawa et al. [31].

With the help of the advanced genetic and other technical tools available, much of the work to understand central control of fertility has been done in rodents, specifically laboratory mice. To study systemic estradiol regulation, both stages of the estrous cycle characterized by negative (diestrus) and positive (proestrus) feedback and hormone manipulation have been used $[32,33]$. With regard to the latter, one paradigm utilizes ovariectomy (OVX) with low estradiol replacement $(\mathrm{OVX}+\mathrm{E}$, negative feedback), followed by a subsequent estrogen injection several days later to induce positive feedback $(\mathrm{OVX}+\mathrm{E}+\mathrm{E})$; this is referred as the estradiol rise model [34]. Another paradigm utilizes OVX with or without a constant high physiological level of estradiol [17]. This daily surge model exhibits a diurnal switch in estradiol feedback, with LH levels lower in estradiol-treated than OVX mice due to estradiol negative feedback in the morning $(\mathrm{OVX}+\mathrm{E} \mathrm{AM})$ and higher in estradiol-treated mice in the afternoon due to positive feedback $(\mathrm{OVX}+\mathrm{E} \mathrm{PM})$. As with $\mathrm{LH}$ in vivo, GFP-identified GnRH neurons in brain slices prepared from this model exhibit low firing rates and release frequency in $\mathrm{OVX}+\mathrm{E} \mathrm{AM}$ mice and high firing rates and release frequency in OVX+E PM mice $[17,18]$. Fast synaptic transmission to and intrinsic membrane properties and ionic conductances of GnRH neurons are both altered by estradiol in this model [35-40]. Similar changes occur between positive feedback during the cycle $[33,41]$. Recent studies further demonstrated that GnRH neurons integrate fast synaptic and intrinsic changes to increase firing rates during positive feedback [42].

\section{Estrogen Receptors Involved in Systemic Estradiol Feedback}

The physiological responses to systemic estradiol in regulating reproductive functions are primarily mediated by two known subtypes of nuclear receptors, estrogen re- ceptor $\alpha(E R \alpha)$ and ER $\beta$ [43-45], as well as membraneassociated receptors (GPR30 and mER) [46-48]. In rodents and humans, the two nuclear receptors are encoded by Esr1 (human ESR1) and Esr2 (human ESR2), respectively. Both ER $\alpha$ and ER $\beta$ typically act as ligand-activated transcription factors [49], by either binding directly to estrogen response elements or interacting with other proteins to alter gene expression $[50,51]$. ER $\alpha$ and $\operatorname{ER} \beta$ can also modulate nongenomic membrane-associated signaling cascades [47, 52-55]. Genomic and nongenomic actions of ERs are evident for many reproductive processes $[50,56]$. For example, signaling via the estrogen response element is needed for estradiol-induced changes in $\mathrm{GnRH}$ neuron firing rate [57], whereas nonclassical signaling also plays a role in this response at the pituitary [58]. Mice with global knockout of ERa or ER $\beta$ show distinct reproductive deficits. ERaKO mice are infertile and have disrupted reproductive tracts including hypoplastic uteri and large hemorrhagic cysts and absence of corpora lutea in the ovaries [59]. In contrast, ER $\beta K O$ mice are fertile but have fewer and smaller litters [59, 60]. Further, ERaKO, but not ER $\beta K O$, female mice exhibit atypically elevated serum LH in ovary-intact mice compared to their littermate controls. Likely related to this, estradiol replacement in OVX ERaKO females does not reduce LH [61]. A neuron-specific ERa KO mouse model shares similarly impaired negative feedback as the ERaKO mice as well as disrupted positive feedback marked by an absence of estradiol-induced LH surge release [62]. Together, these observations suggest that estradiol negative and positive feedback rely on estrogen signaling via ERa. Although tightly regulated by estradiol, GnRH neurons do not express detectable levels of ERa; their response is thus at least in part attributable to estradiol action through upstream ERa-expressing neurons [63, 64]. The upstream neurons that have by far been the subject of the most investigation for its role in estradiol feedback over the past 15 years are kisspeptin neurons.

\section{Kisspeptin Signaling}

The discovery of the link between KISS1 (produce kisspeptin) and KISS1R (produce kisspeptin receptors) genes and puberty and fertility comes from human studies. Patients carrying mutations in either of these genes exhibit idiopathic hypothalamic hypogonadism, impaired pubertal maturation, and low-amplitude LH pulses $[65,66]$. Transgenic mice that lack Kiss 1 or Kiss $1 r$ exhibit a similar hypothalamic hypogonadism phenotype 
$[66,67]$. Kisspeptin is expressed in several organs including gonads, pancreas, colon, pituitary, and brain $[68,69]$. In mouse hypothalamus, kisspeptin expression is restricted to two regions: the arcuate nucleus and the anteroventral periventricular nucleus (AVPV) [70]. Both populations express $\mathrm{ER} \alpha, \sim 99 \%$ in the arcuate and $\sim 70 \%$ in the AVPV [71]. Arcuate kisspeptin expression is similar in both sexes, whereas AVPV kisspeptin expression is more extensive in females [72]. When estradiol is elevated, kisspeptin mRNA expression is increased in the AVPV and decreased in the arcuate nucleus [73, 74].

Projections from kisspeptin neurons to $\mathrm{GnRH}$ neurons vary with species [75-77]. In the mouse, kisspeptin fibers from the AVPV form direct appositions to GnRH cell bodies, whereas fibers from arcuate kisspeptin neurons are primarily opposed to $\mathrm{GnRH}$ processes that are running through the arcuate nucleus to the median eminence [78-80]. Both of these configurations support a direct kisspeptin-GnRH connection. In situ hybridization for Kiss1r and Kiss1r promoter-driven lacZ demonstrate that GnRH neurons express kisspeptin receptors [81, 82]. Bath application of kisspeptin to brain slices robustly increases GnRH firing activity and release [18, 83, 84]; kisspeptin injection in vivo increases GnRH release and subsequent LH release [85]. From a loss-of-function standpoint, blockade of kisspeptin action by injecting an antibody or a specific antagonist decreases GnRH activity, LH release, and estrous cyclicity $[72,86]$. Deletion of Kiss $1 r$ from GnRH neurons recapitulates the Kiss Ir KO phenotypes; re-introducing Kiss1r expression to $\mathrm{GnRH}$ neurons in Kiss $1 r \mathrm{KO}$ mice rescues the deficits [87]. These observations indicate that kisspeptin - GnRH circuitries are critical for normal reproduction. The differential regulation of kisspeptin by estradiol in arcuate and AVPV kisspeptin neurons set up the working hypothesis that these regions have distinct roles in mediating estradiol negative and positive feedback, respectively [88].

\section{Arcuate Kisspeptin Neurons and Estradiol Negative Feedback}

Evidence that suggested a link between arcuate nucleus neurons and LH pulses came from early lesion studies, well before the discovery of kisspeptin: ablation of the arcuate nucleus abolished LH pulses in rats and monkeys $[89,90]$. Further, correlation of peaks in neuronal multiunit activity (MUA) in the mediobasal hypothalamus $(\mathrm{MBH})$, which contains the arcuate, with pulsatile LH release was demonstrated in several species including mon- keys, goats, sheep, and rodents [91-94]. In rats, sheep, and goats, only a small percent of GnRH neurons are in the $\mathrm{MBH}$, suggesting that other neurons in the $\mathrm{MBH}$ are involved in generating MUA peaks and perhaps pulse generation.

Identification of a role of kisspeptin in fertility refocused attention on the arcuate region, as arcuate kisspeptin neurons exhibit two characteristics needed for steroid-regulated GnRH/LH pulse frequency. First, their activity is associated with pulsatile LH release [95]. Second, they can directly sense steroid feedback [77]. This brings up the intriguing possibility that generation and steroid regulation of $\mathrm{GnRH}$ pulses may be combined into one system. Arcuate kisspeptin neurons coexpress two additional peptides involved in regulating reproduction, neurokinin $\mathrm{B}(\mathrm{NKB})$ and dynorphin $\mathrm{A}$, and are often referred to as KNDy neurons $[77,96,97]$. Intracerebroventricular injection of NKB and dynorphin alters LH pulse frequency and associated MUA activity peaks in goats and $\mathrm{LH}$ pulse frequency in ewes; NKB increased the frequency of MUA peaks in the arcuate and LH pulse frequency. In contrast, dynorphin inhibited MUA peaks and LH secretion, whereas blocking its action increased frequency of both central and pituitary output $[98,99]$. Bath application of these two peptides to mouse brain slices has a corresponding effect on KNDy neurons; NKB is excitatory, dynorphin inhibitory [100-102]. These changes may be attributable to direct action of the peptides on KNDy neurons, as these neurons form interconnected circuits [102] and most KNDy neurons express the NKB receptor, NK3R, with a smaller percentage of these cells expressing the dynorphin-specific kappa-opioid receptor (KOR) $[97,103]$. Long-term monitoring of KNDy neuron activity revealed that they exhibit spontaneous peaks and nadirs in firing rate [104]. This pattern can be altered when NK3R is activated; blocking KOR, however, did not affect the patterns [104]. This difference may be explained by the observation that fewer KNDy neurons express KOR than NK3R [105], although the higher efficacy of in vivo KOR blockade versus in brain slices may indicate dynorphin acts via cell populations not present in the brain slice to inhibit LH pulses in vivo. Together these observations point to a hypothesis that KNDy neurons form an interconnected network that is modulated by its peptide products to determine their rhythmic output to GnRH neurons, thus affecting $\mathrm{LH}$ pulses.

To test the sufficiency of KNDy neurons to trigger a pulse of LH release, studies were conducted using Credependent mice and adeno-associated viral (AAV) vectors. Activation of KNDy neurons using light induced 
stimulation of channelrhodopsin2 (ChR2) in vivo triggers a pulse of LH release, confirming their capability to elicit LH release either directly or indirectly [106]. The calcium indicator GCaMP6 and fiber photometry were utilized to estimate bulk arcuate kisspeptin neuron activity based on fluctuations in calcium-sensitive fluorescence. Increases in fluorescence of KNDy neurons correlates with LH pulse release $[95,107]$. From a loss-of-function standpoint, KNDy neuron ablation was achieved by delivering diphtheria toxin A to mice expressing the toxin receptor in kisspeptin cells. When done on postnatal day 20, when the diphtheria toxin receptor is primarily expressed in arcuate but not AVPV kisspeptin neurons [108], these mice exhibit persistent diestrus as adults, suggesting that KNDy neurons are required for establishing/ maintaining cyclicity [109]; of note, the integrity of the AVPV kisspeptin population was not assessed in adult mice in these studies. Similarly, blocking the release of neuropeptides and neurotransmitters from KNDy neurons using a Cre-dependent AAV expressing the light chain of tetanus toxin halted the reproductive cycle, with mice again remaining in diestrus; these mice also had decreased LH levels [110]. These in vivo studies further suggest that KNDy neurons are at least a component of the pulse-generating or -conveying system.

Besides displaying rhythmic activity, KNDy neurons are also capable of being directly regulated by steroids, including estradiol. This modulation happens at multiple levels. First, estradiol decreases kisspeptin, NKB, and NK3R expression in these cells $[73,74,97]$. Second, estradiol reduces the excitatory effect of NKB and enhances the inhibitory effect of dynorphin on KNDy neuron firing rate $[100,111]$. The effects of steroids on KNDy neuron firing rate is complicated. In early short-term extracellular recordings of these cells, results were inconsistent but typically revealed no effect of castration in females or males [100, 101]. More recent work examining OVX versus OVX+E females demonstrated a trend for estradiol to reduce firing rate; no statistical difference was revealed in two-way ANOVA (Fig. 1a) [112], but a direct comparison of these groups with greater power in a recent preliminary report revealed a suppression in OVX+E females [113]. There is only one study of long-term firing pattern, which was done in male mice. This work suggests that sex steroids, including estradiol, modulate firing patterns of KNDy neurons but not the overall mean firing rate over a couple of hours [104]. Fast synaptic inputs to KNDy neurons are also regulated by estradiol, as estradiol decreases glutamatergic input frequency (Fig. 1c) and GABAergic input amplitude to KNDy neurons $[112,114]$.
These suggest that estradiol may alter KNDy neuron activity both directly and via modulating afferent systems. With regard to the latter, the interconnected nature of KNDy neurons and their use of glutamate as a cotransmitter [71] may indeed be a direct KNDy neuron network effect, whereas GABA changes are more likely via distinct cells.

The importance of estradiol-sensing in KNDy neurons is demonstrated by two Cre-lox genetic mouse models: a kisspeptin-specific ER $\alpha$ knockout (KERKO) and an NKB (Tac2 gene product)-specific ERa knockout (TERKO) $[115,116]$. In KERKO mice, deletion of ERa from kisspeptin cells leads to advanced vaginal opening during development but disrupted cyclicity (persistent estrus) in adults [116]. In this model, however, ER $\alpha$ is removed from both AVPV and arcuate kisspeptin neurons as well as other kisspeptin cells located centrally and peripherally, making the interpretation of a specific role of arcuate kisspeptin neurons difficult. In the TERKO model, ERa is removed largely from the arcuate kisspeptin neurons in the brain [115]. TERKO mice also exhibited advanced vaginal opening and prolonged estrus, similar to the KERKO mice, suggesting that the phenotypes may largely attribute to KNDy neurons and that ERa in kisspeptin cells, particularly KNDy neurons, is critical for reproductive function including puberty and cyclicity.

KERKO mice have also been used to study the mechanisms of how estradiol modulates KNDy neuron activity and LH pulse generation. To test if KERKO mice are able to respond to negative feedback regulation, plasma $\mathrm{LH}$ levels were measured in OVX and OVX+E control and KERKO mice. The post-OVX LH rise in KERKO mice was reduced compared to controls, but estradiol was able to reduce LH levels in both groups [117]. These findings led to the postulate that arcuate kisspeptin neurons may not be necessary to mediate negative feedback. Examination of LH pulses with frequent sampling revealed elevated pulse frequency in ovary-intact KERKO mice compared to estrous controls, suggesting that frequencymodulating effects of estradiol are likely, at least in part, mediated by ER $\alpha$ in kisspeptin cells [112]. Interestingly, KERKO mice are also less responsive to kisspeptin and GnRH challenge in terms of LH release [112]. Biophysical studies of KNDy neurons in KERKO mice further reveal several critical roles ERa plays. KNDy neurons in KERKO mice exhibited elevated firing rate (Fig. 1a) and received elevated spontaneous and action potential-independent glutamatergic transmission compared to controls [112] (Fig. 1c). Further, when OVX versus OVX+E mice were compared, estradiol suppressed glutamatergic transmis- 


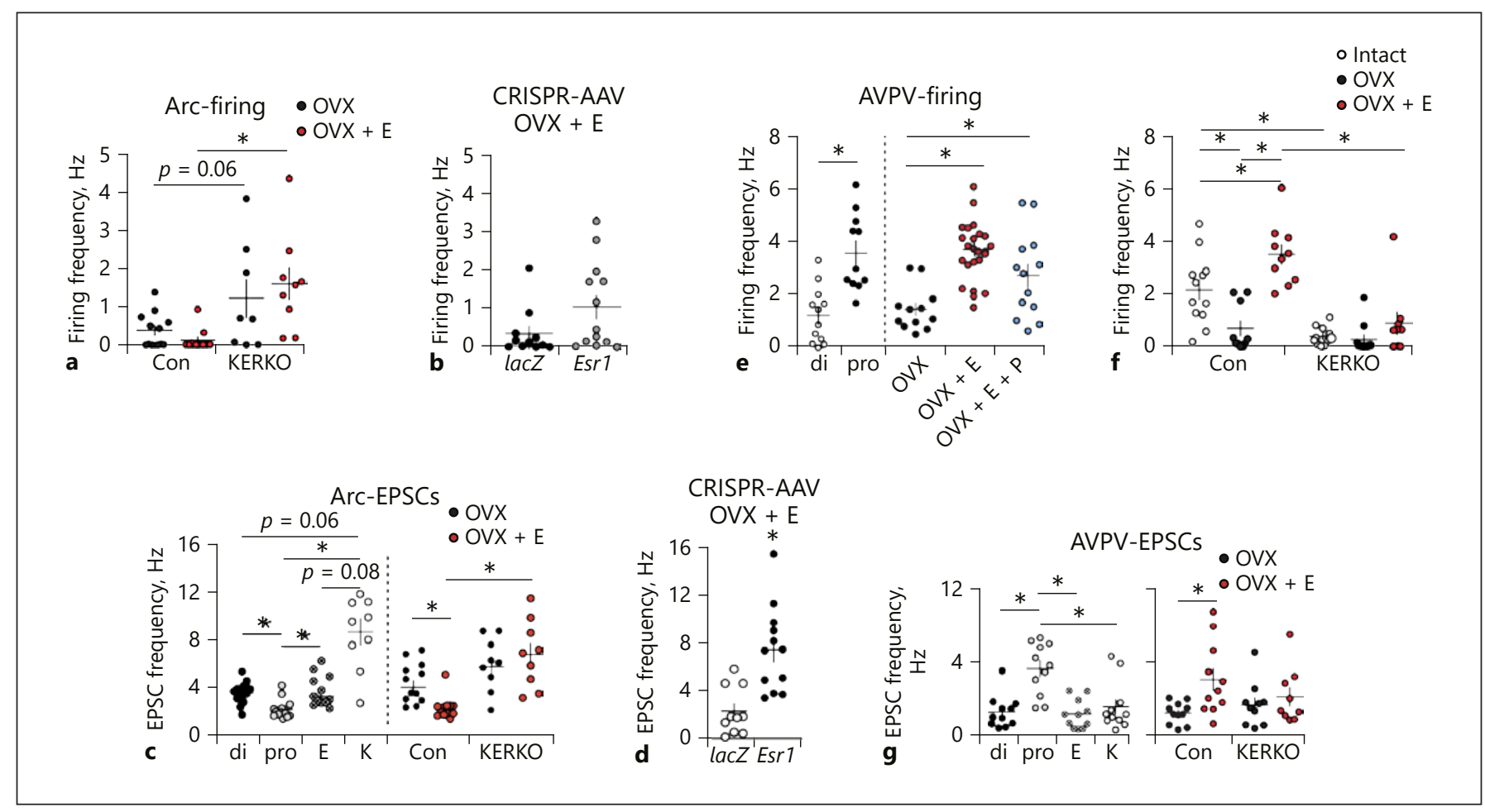

Fig. 1. Estradiol regulation of firing rate and EPSC frequency in arcuate and AVPV kisspeptin neurons of the hypothalamus. a Firing rate of arcuate kisspeptin neurons is elevated in cells from KERKO compared to control mice. $\mathbf{b}$ Firing rate is not different between cells from Arc-AAV-Esr1 and Arc-AAV-lacZ OVX+E mice. c Spontaneous glutamatergic EPSC frequency is regulated by cycle stage (left) and estradiol (right) in arcuate kisspeptin neurons. E, estrus; K, KERKO. d Knockdown of ERa targeted to the arcuate increases glutamatergic inputs to arcuate KNDy neurons. e Firing rate of AVPV kisspeptin neurons is elevated during proestrus (left) and by estradiol (right). $\mathbf{f}$ The firing rate decreases in cells from KERKO compared to control and is no longer estradiolsensitive. g Spontaneous glutamatergic EPSC frequency is regulated by cycle stage (left) and estradiol (right) in AVPV kisspeptin neurons. ${ }^{*} p<0.05$; adapted from $[112,119,137]$ with permission. KERKO, kisspeptin-specific ERa knockout; OVX, ovariectomy; AVPV, anteroventral periventricular nucleus. sion and firing rate in controls but not in KERKO mice (Fig. 1a, c). This suggests that the lack of ERa in kisspeptin cells leads to a lack of response to estradiol in these cells [112]. The loss of ERa signaling and subsequent elevated LH pulse frequency may contribute to the disrupted cyclicity [112], as modulation of $\mathrm{GnRH} / \mathrm{LH}$ frequency is critical for maintaining normal cyclicity.

Although informative to understand estradiol negative feedback on GnRH-KNDy network, this Cre-loxbased KERKO model has its own caveats. Specifically, it is impossible to distinguish activational and organizational roles of ERa, as ERa is deleted as soon as the kisspeptin gene turns on, before birth in KNDy neurons and before puberty in AVPV kisspeptin neurons [108, 118]. Further, ERa is deleted from all kisspeptin cells. Spatial and temporal precision is needed to dissect the role of KNDy neurons in reproduction. To overcome these ca- veats, a CRISPR-Cas9 approach was employed to reduce ERa in the arcuate kisspeptin neurons in adult mice [119]. This model utilized the Cre-lox system to express the Cas9 protein in kisspeptin cells. Then, in adult mice, an AAV vector that expresses an sgRNA that targets Esr 1 (ERa gene) was injected into the arcuate region (Arc$A A V-E s r 1)$. As a control, an AAV vector targeting the lacZ gene was introduced in the same manner (Arc-AAVlacZ); these mice were not different from control females for the parameters measured [119]. To reduce the caveats of CRISPR off-target effects, two independent sgRNAs were used and independently tested; no detectable differences were found between these. This approach achieved partial ( 65\%) knockdown of ERa in kisspeptin cells specifically in the arcuate region. Despite the partial nature of this knockdown, these Arc-AAV-Esr1 mice exhibited disrupted reproductive cyclicity, spending prolonged 


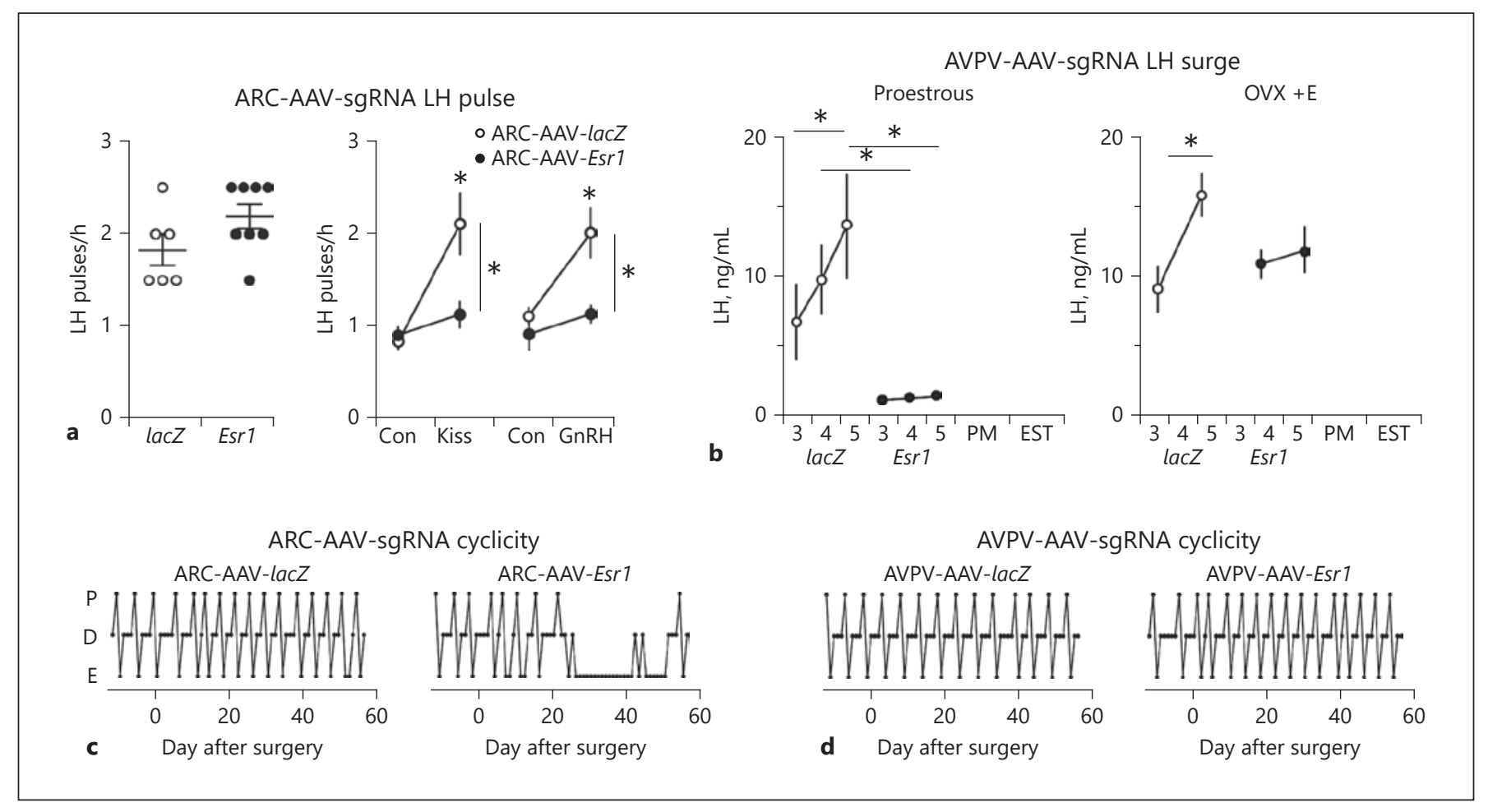

Fig. 2. Distinct roles of arcuate and AVPV kisspeptin neurons in regulating estradiol feedback and reproductive function. a Knockdown of ERa in arcuate kisspeptin neurons did not alter LH pulse frequency on estrus (left) but desensitized the LH response to kisspeptin and GnRH challenge. b Knockdown of ERa in AVPV kisspeptin neurons blunted the proestrous (left) and estradiol-in-

time in estrus, and had reduced response to kisspeptin and $\mathrm{GnRH}$ administration compared to Arc-AAV-lacZ; both of these responses are similar to the KERKO model (Fig. 2a, c) $[112,115,116,119]$. In contrast to KERKO mice, which exhibit increased LH pulse frequency, no changes of pulse frequency were observed in Arc-AAVEsr1 mice (Fig. 2a). This may be attributable to these mice being singly housed, whereas the KERKO mice examined for LH pulses were group housed; single housing can increase stress, which makes pulses harder to detect [120].

In brain slices, KNDy neurons in Arc-AAV-Esr1 mice also shared several biophysical similarities with cells from KERKO mice. Specifically, these neurons tend to be more active (Fig. 1b; $p<0.05$ two-tailed $t$ test of log-normalized data, $p<0.14$ two-tailed Mann-Whitney U test of original data) and receive more glutamatergic inputs compared to Arc-AAV-lacZ (Fig. 1d) [112, 119]. Taken together, ERa in KNDy neurons is required to maintain the typical function of the KNDy neuron network and female cycles, independent of developmental roles.

Brain Sites for Estradiol Feedback duced (right) surges. c, d Knockdown of ERa in arcuate (c) but not AVPV (d) kisspeptin neurons alter reproductive cyclicity. Adapted from [119]. KERKO, kisspeptin-specific ERa knockout; OVX, ovariectomy; AVPV, anteroventral periventricular nucleus; LH, luteinizing hormone.

\section{AVPV Kisspeptin Neurons and Estradiol Positive Feedback}

As with the arcuate region and pulses, the AVPV region was associated with surge generation long before the discovery of kisspeptin. AVPV neurons are sexually dimorphic, with more neurons in females, and many express ER $\alpha[121,122]$. They exhibit increased cFos expression, an immediate early gene with expression often correlated with increased neuronal activity, during the LH surge when GnRH release is elevated [123, 124]. Lesions of the AVPV block the preovulatory as well as the estradiol-induced LH surge [125-127]. AVPV kisspeptin neurons, as a subset of AVPV neurons, share these characteristics: they are sexually dimorphic, ERa positive (more than $70 \%)$, and express cFos during the LH surge $[78,88$, 128-130]. At least $1 / 3$ of AVPV kisspeptin neurons communicate with GnRH cell bodies; these neurons almost all express ERa [131]. Elevated activity often correlates with neurotransmitter and neuropeptide release, thus cFos ex- 
pression may indicate increased activity and release from AVPV kisspeptin neurons to their efferent projections including GnRH neurons. Besides expressing the potent GnRH stimulator kisspeptin, AVPV kisspeptin neurons coexpress tyrosine hydroxylase $(\mathrm{TH}, \sim 70 \%)$ and utilize GABA $(\sim 75 \%)$ and glutamate ( 20\%) [71, 132], both of which excite GnRH neurons, as cotransmitters [133, 134]. The role of dopamine, a product of TH-expressing neurons, on GnRH neuron function is not very well defined. When TH is knocked out of kisspeptin cells, mice exhibit normal reproduction [135], suggesting that kisspeptin and GABA might be the main resource for $\mathrm{GnRH}$ excitation [136]. Together, these observations help to build a model that AVPV kisspeptin neurons are regulated by estradiol to increase activity during the $\mathrm{GnRH} /$ LH surge.

To investigate this model at a more mechanistic level, studies were conducted to test if AVPV kisspeptin neurons are more excitable during estradiol positive feedback (proestrus) compared to negative feedback (diestrus). Extracellular recordings were made of GFP-identified AVPV kisspeptin neurons in brain slices. These neurons fire more action potentials and exhibit a greater degree of rapid action potential bursts on proestrus compared to diestrus and estrus (Fig. 1e) [137, 138]. Hormonal manipulations (OVX $+\mathrm{E}, \mathrm{OVX}+\mathrm{E}+$ progesterone) suggest that it is primarily estradiol that mediates these changes as $\mathrm{OVX}+\mathrm{E}$ mice recapitulate the firing characteristics observed in cells from proestrus mice, whereas $\mathrm{OVX}+\mathrm{E}+\mathrm{P}$ mice are not different from those receiving only estradiol replacement (Fig. 1e). Several ionic conductances have been identified in AVPV kisspeptin neurons, including hyperpolarization-activated cation channels, T-type calcium channels, and persistent sodium channels $[137,139$, 140]. All three of these channels have been demonstrated to promote burst firing and pace-making in other neurons [141-143]. Both electrophysiological recordings measuring ionic currents and mRNA expression of these ion channel genes in pooled AVPV kisspeptin cells suggest that these conductances are upregulated by estradiol $[137,139,140]$. These increases in burst-related ionic conductances in AVPV kisspeptin neurons may contribute to the increased firing activity of these neurons during the time of the GnRH/LH surge and provide a mechanism for how estradiol modulates AVPV kisspeptin neuronal firing to facilitate positive feedback. Besides exhibiting cycle/estradiol-dependent ionic conductances, AVPV kisspeptin neurons also received increased excitatory glutamatergic inputs (Fig. $1 \mathrm{~g}$ ) and decreased inhibitory GABAergic transmission during positive feedback
$[112,114]$, tilting the balance toward excitation during positive feedback. These observations suggest that estradiol-sensing positive feedback circuitry may extend beyond AVPV kisspeptin neurons, as their upstream inputs are also modulated by estradiol.

To test if stimulation of AVPV kisspeptin neurons is sufficient to generate $\mathrm{LH}$ secretion in vivo, ChR2 was targeted to these cells. Photostimulation of AVPV kisspeptin neurons for $\sim 15 \mathrm{~min}$ induced LH release secretion of similar amplitude to the endogenous LH surge, but the time course was more similar to a pulse than a prolonged surge release [136]. These results not only demonstrate that activation of AVPV kisspeptin cells likely increases $\mathrm{GnRH}$ and thereby LH release but also suggest that induction of surge release may need prolonged activation of AVPV kisspeptin neurons.

The KERKO model has also been used to study the role of ERa in kisspeptin cells, including AVPV kisspeptin neurons, in positive feedback. KERKO mice remain in estrus and exhibit high circulating estradiol, thus an estradiol rise surge model was used to study estradiol positive feedback. KERKO mice failed to generate estradiolinduced LH surges, suggesting that ERa in kisspeptin cells is required for estradiol positive feedback [117]. From a biophysical aspect, AVPV kisspeptin neurons from KERKO mice are less excitable (Fig. 1f) and receive fewer glutamatergic inputs compared to littermate controls (Fig. 1g). Further, these typically estradiol-sensitive parameters are also no longer regulated by estradiol in OVX versus OVX+E mice (Fig. 1f, g) $[112,119]$. This indicates that ERa plays a necessary role in modulating the excitability of AVPV kisspeptin neurons to trigger an LH surge [119]. Although informative, this model also has the caveats mentioned above regarding a lack of spatial and temporal precision. These caveats are potentially more serious in the AVPV population as kisspeptin cell number in the AVPV drops when estradiol is removed.

The CRISPR approach again provides space- and time-specific regulation of ERa in AVPV kisspeptin neurons. Reduction of Esr 1 in the AVPV region was achieved as above using kisspeptin-Cre targeting of Cas9 and delivery of sgRNAs targeting the Esr1 gene (AVPV-AAVEsr1) in adulthood [119]. In AAV-AVPV-Esr1 mice, $\sim 35 \%$ of kisspeptin neurons express ERa versus $70 \%$ in control mice that received AAV-AVPV-lacZ. To test if ER $\alpha$ deletion in AVPV kisspeptin neurons alters neuronal firing properties in OVX+E mice, whole-cell recordings were paired with post hoc testing (immunofluorescence of biocytin-labeled recorded cells or single-cell qPCR) to determine expression of ER $\alpha$ in each recorded 
Fig. 3. Schematic diagram of estradiol feedback regulation on ERa in AVPV and arcuate kisspeptin neurons in adulthood. Knockdown of ERa in AVPV kisspeptin neurons blunted the LH surge but did not alter reproductive cyclicity, whereas knockdown of ERa in arcuate kisspeptin neurons disrupted estrous cyclicity. From [119]. $\mathrm{ER} \alpha$, estrogen receptor $\alpha$; LH, luteinizing hormone; AVPV, anteroventral periventricular nucleus; GnRH, gonadotropin-releasing hormone.

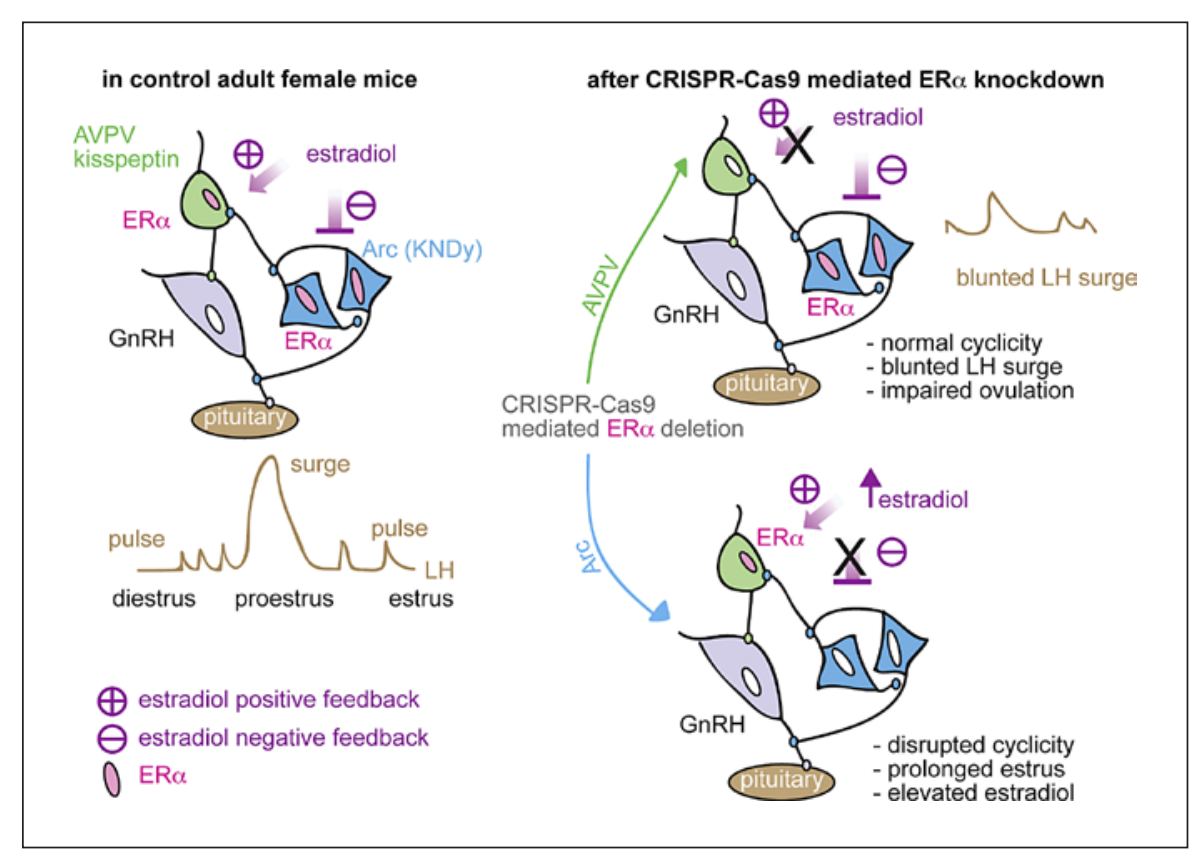

cell. In OVX+E mice with AAV-AVPV-AAV-Esr1, only ERa-negative AVPV kisspeptin neurons exhibited decreased firing rate and bursts compared to AVPV-AAVlacZ-infected cells and AVPV-AAV-Esr1 uninfected cells [119]. These responses are similar to changes that occur in these cells in KERKO mice, suggesting that the primary effect of estradiol on the intrinsic electrophysiological properties of these cells is activational.

From a systemic aspect, these mice maintained normal cyclicity for at least 2 months post surgery; in contrast, disruptions of cyclicity when the arcuate kisspeptin population was targeted began to emerge within 3 weeks (Fig. 2d) [119]. It is possible that the remaining ERaexpressing AVPV kisspeptin neurons are sufficient to maintain cyclicity. Alternatively, cyclicity may be maintained by other neurons, such as the arcuate KNDy neurons. In a recent study, genetic deletion of ER $\alpha$ broadly in the POA and AVPV region, but not arcuate, of adult female mice produced persistent estrus and decreased the amplitude of the estradiol-induced LH surge using the estradiol rise surge induction model [144]. In the area covered by this knockdown, many cells besides AVPV kisspeptin neurons express ERa [145], making it difficult to ascribe these results to a specific cell type.

Despite having normal cycles, AVPV-AAV-Esr1 mice had, at best, blunted LH surges, both proestrus and estradiol-induced (Fig. 2b). Although a reduced proestrus surge could be attributable to reduced estradiol levels, this caveat is minimized by the demonstration that estradiol- induced surges are also reduced. Further, the estradiol levels produced in the AVPV-AAV-Esr1 mice are sufficient to induce vaginal cornification. Consistent with blunted LH surges, ovarian histology showed reduced or absent corpora lutea in two-thirds of knockdown mice compared to AVPV-AAV-lacZ control mice [119]. These results support and extend much research in the field by demonstrating that ERa in AVPV kisspeptin neurons is important for positive feedback and LH surge generation.

\section{Conclusion and Future Directions}

Application of modern genetic approaches to the longexisting questions of where estradiol acts to bring about negative and positive feedback has brought more insights into the regulation of $\mathrm{GnRH} / \mathrm{LH}$ pulses and surges. There is now strong evidence that arcuate and AVPV kisspeptin neurons play distinct roles in mediating the response to systemic changes in estradiol, regulating cyclicity and the LH surge, respectively. Because CRISPR-mediated changes were induced in adults, we can conclude that the observations are not attributable to a loss of ERa action during development (Fig. 3).

Several major areas of investigation remain regarding the kisspeptin-GnRH circuitry. First, AVPV and arcuate kisspeptin neurons receive and process estradiol signals, but we do not know if estradiol action in their estrogensensitive afferents is critical. It is possible that reducing 
ER $\alpha$ in our target kisspeptin populations merely blocked processing of incoming signals from the true first-order responding cells. Are these signals from upstream cells required and, if so, what and where are these neurons? Further, do AVPV kisspeptin neurons require the input from arcuate kisspeptin neurons to mediate the switch from negative to positive feedback? Multi-region spectrum-specific fiber photometry approaches may be applied to monitor simultaneously the activity of AVPV and arcuate neuronal activity in each distinct reproductive stage [146, 147]. This approach could also be utilized to test if there is synchrony between arcuate kisspeptin neurons and GnRH neurons.

Second, how AVPV and arcuate kisspeptin neurons convey their feedback modulation to GnRH neurons is not completely understood. Does increased AVPV and/ or arcuate kisspeptin neuronal activity lead to increased neurosecretion? Assuming from work on other systems that the answer is yes, are the cotransmitters and other peptides in these cells important or is kisspeptin the primary player? Further, is all of the kisspeptin communication received directly by GnRH neurons? Studies in global Kiss1r knockout mice have suggested that replacing these receptors only in GnRH neurons restore fertility [87]. Further work on these mice, however, has demonstrated that aspects of steroid feedback, gonadal structure, and gonadotropin release are not fully restored [148]. Consistent with this latter finding, kisspeptin treatment increases fast synaptic transmission to $\mathrm{GnRH}$ neurons, indicating that there are indirect pathways involving at least GABA and glutamate through which this neuromodulator may influence GnRH output [149]. One population of interest in this regard are neurons that utilize nitric oxide (NO) as a neurotransmitter; NO has been proposed as a synchrony signal to GnRH neurons [150, 151]. Further, NO synthase-expressing neurons in the median preoptic area also express Kiss $1 r$ [152], making them another possible intermediate between kisspeptin and GnRH neurons. Comprehensive projection mapping and direct stimulation and/or inhibition of NO synthase neurons in vivo are needed to test this postulate.

Third, it is still not clear how estradiol regulates gene expression profiles to change intrinsic neuronal activity of AVPV and arcuate kisspeptin neurons. Of particular interest in this regard are the mechanisms underlying the many-hour delay from achieving a surge-inducing level of estradiol and the onset of the GnRH/LH surge. The length of this delay and the ability to remove estradiol before the surge is initiated without affecting it imply genomic mechanisms [12], but detailed temporal profiling of gene expression spanning this gap is lacking. Advanced single-cell and/or single-nucleus sequencing approaches may shed light on the steps involved in estradiol feedback regulation on these cells. Recently, two droplet-based single-cell RNA-sequencing studies of the arcuate and POA region provide intriguing data for identifying different populations of neurons and their transcriptomes, including the two kisspeptin populations; this detailed information allows potential reimagining of how different neuronal populations are related to one another $[153,154]$. Future studies should include studying these neurons at precise times under different hormone treatments and/or distinct cycle stages to reveal the time course of estradioldependent gene expression profiles and generate hypotheses for future physiological investigations.

\section{Support}

Supported by National Institute of Health/Eunice Kennedy Shriver National Institute of Child Health and Human Development R01 HD41469.

\section{Disclosure Statement}

The authors have nothing to disclose.

\section{References}

1 Fink G. Neuroendocrine Regulation of Pituitary Function. Neuroendocrinology in Physiology and Medicine. Totowa: Humana Press; 2000. pp. 107-33.

2 Plant TM, Zeleznik AJ, Herbison AE. Physiology of the Adult Gonadotropin-Releasing Hormone Neuronal Network. Knobil and Neill's Physiology of Reproduction; 2015. pp. 399-467.
3 Silverman A, Livne I, Witkin JW. The gonadotrophin-releasing hormone (GnRH), neuronal systems: immunocytochemistry and in situ hybridization. In: Neill J, editor. Physiology of reproduction. 2nd ed. New York: Raven Press; 1994. pp. 1683-706.

4 Knobil E, Plant TM, Wildt L, Belchetz PE, Marshall G. Control of the rhesus monkey menstrual cycle: permissive role of hypothalamic gonadotropin-releasing hormone. Science. 1980 Mar;207(4437):1371-3.
5 Clarke IJ, Cummins JT. The temporal relationship between gonadotropin releasing hormone $(\mathrm{GnRH})$ and luteinizing hormone (LH) secretion in ovariectomized ewes. Endocrinology. 1982 Nov;111(5):1737-9.

6 Moenter SM, Brand RC, Karsch FJ. Dynamics of gonadotropin-releasing hormone $(\mathrm{GnRH})$ secretion during the GnRH surge: insights into the mechanism of GnRH surge induction. Endocrinology. 1992 May;130(5):297884. 
7 Marshall JC, Griffin ML. The role of changing pulse frequency in the regulation of ovulation. Hum Reprod. 1993 Nov;8 Suppl 2:57-61.

8 Haisenleder DJ, Khoury S, Zmeili SM, Papavasiliou S, Ortolano GA, Dee C, et al. The frequency of gonadotropin-releasing hormone secretion regulates expression of $\alpha$ and luteinizing hormone $\beta$-subunit messenger ribonucleic acids in male rats. Mol Endocrinol. 1987 Nov; 1(11):834-8.

9 Wildt L, Häusler A, Marshall G, Hutchison JS, Plant TM, Belchetz PE, et al. Frequency and amplitude of gonadotropin-releasing hormone stimulation and gonadotropin secretion in the rhesus monkey. Endocrinology. 1981 Aug;109(2):376-85.

10 Plant TM, Zeleznik AJ. Knobil and Neill's physiology of reproduction 4 th edition. Elsevier, 2015.

11 Goodman RL, Daniel K. Modulation of pulsatile luteinizing hormone secretion by ovarian steroids in the rat. Biol Reprod. 1985 Mar; 32(2):217-25.

12 Evans NP, Dahl GE, Padmanabhan V, Thrun LA, Karsch FJ. Estradiol requirements for induction and maintenance of the gonadotropin-releasing hormone surge: implications for neuroendocrine processing of the estradiol signal. Endocrinology. 1997 Dec;138(12): 5408-14.

13 Leipheimer RE, Bona-Gallo A, Gallo RV Ovarian steroid regulation of pulsatile luteinizing hormone release during the interval between the mornings of diestrus 2 and proestrus in the rat. Neuroendocrinology. 1985 Sep;41(3):252-7.

14 Adams TE, Norman RL, Spies HG. Gonadotropin-Releasing Hormone Receptor Binding and Pituitary Responsiveness in EstradiolPrimed Monkeys. Science. 1981 Sep;213: 1388-90.

15 Barrell GK, Moenter SM, Caraty A, Karsch FJ Seasonal changes of gonadotropin-releasing hormone secretion in the ewe. Biol Reprod. 1992 Jun;46(6):1130-5.

16 Hileman SM, Jackson GL. Regulation of gonadotrophin-releasing hormone secretion by testosterone in male sheep. J Reprod Fertil Suppl. 1999;54:231-42.

17 Christian CA, Mobley JL, Moenter SM. Diurnal and estradiol-dependent changes in gonadotropin-releasing hormone neuron firing activity. Proc Natl Acad Sci USA. 2005 Oct; 102(43):15682-7.

18 Glanowska KM, Venton BJ, Moenter SM. Fast scan cyclic voltammetry as a novel method for detection of real-time gonadotropin-releasing hormone release in mouse brain slices. J Neurosci. 2012 Oct;32(42):14664-9.

19 Caraty A, Locatelli A, Martin GB. Biphasic response in the secretion of gonadotrophin-releasing hormone in ovariectomized ewes injected with oestradiol. J Endocrinol. 1989 Dec;123(3):375-82.
20 Pielecka J, Quaynor SD, Moenter SM. Androgens increase gonadotropin-releasing hormone neuron firing activity in females and interfere with progesterone negative feedback. Endocrinology. 2006 Mar;147(3):14749.

21 Pielecka J, Moenter SM. Effect of steroid milieu on gonadotropin-releasing hormone-1 neuron firing pattern and luteinizing hormone levels in male mice. Biol Reprod. 2006 May;74(5):931-7.

22 Karsch FJ, Cummins JT, Thomas GB, Clarke IJ. Steroid feedback inhibition of pulsatile secretion of gonadotropin-releasing hormone in the ewe. Biol Reprod. 1987 Jun;36(5):120718.

23 Moenter SM, Caraty A, Karsch FJ. The estradiol-induced surge of gonadotropin-releasing hormone in the ewe. Endocrinology. 1990 Sep;127(3):1375-84.

24 Crowder ME, Nett TM. Pituitary content of gonadotropins and receptors for gonadotropin-releasing hormone ( $\mathrm{GnRH})$ and hypothalamic content of GnRH during the periovulatory period of the ewe. Endocrinology. 1984 Jan;114(1):234-9.

25 Sarkar DK, Chiappa SA, Fink G, Sherwood NM. Gonadotropin-releasing hormone surge in pro-oestrous rats. Nature. 1976 Dec; 264(5585):461-3

26 Adams JM, Taylor AE, Schoenfeld DA, Crowley WF Jr, Hall JE. The midcycle gonadotropin surge in normal women occurs in the face of an unchanging gonadotropin-releasing hormone pulse frequency. J Clin Endocrinol Metab. 1994 Sep;79(3):858-64.

27 Pau KY, Berria M, Hess DL, Spies HG. Preovulatory gonadotropin-releasing hormone surge in ovarian-intact rhesus macaques. Endocrinology. 1993 Oct;133(4):1650-6.

28 Xia L, Van Vugt D, Alston EJ, Luckhaus J, Ferin $\mathrm{M}$. A surge of gonadotropin-releasing hormone accompanies the estradiol-induced gonadotropin surge in the rhesus monkey. Endocrinology. 1992 Dec;131(6):2812-20.

29 Karsch FJ, Bowen JM, Caraty A, Evans NP, Moenter SM. Gonadotropin-releasing hormone requirements for ovulation. Biol Reprod. 1997 Feb;56(2):303-9.

30 Kaynard AH, Malpaux B, Robinson JE, Wayne NL, Karsch FJ. Importance of pituitary and neural actions of estradiol in induction of the luteinizing hormone surge in the ewe. Neuroendocrinology. 1988 Sep;48(3): 296-303.

31 Terasawa E. Neuroestradiol in regulation of GnRH release. Horm Behav. 2018 Aug; 104: 138-45.

32 Dror T, Franks J, Kauffman AS. Analysis of multiple positive feedback paradigms demonstrates a complete absence of LH surges and $\mathrm{GnRH}$ activation in mice lacking kisspeptin signaling. Biol Reprod. 2013 Jun;88(6): 146-146.
33 Silveira MA, Burger LL, DeFazio RA, Wagenmaker ER, Moenter SM. GnRH neuron activity and pituitary response in estradiol-induced vs proestrous luteinizing hormone surges in female mice. Endocrinology. 2017 Feb;158(2):356-66.

34 Bronson FH. The regulation of luteinizing hormone secretion by estrogen: relationships among negative feedback, surge potential, and male stimulation in juvenile, peripubertal, and adult female mice. Endocrinology. $1981 \mathrm{Feb} ; 108(2): 506-16$

35 Pielecka-Fortuna J, DeFazio RA, Moenter SM. Voltage-gated potassium currents are targets of diurnal changes in estradiol feedback regulation and kisspeptin action on gonadotropin-releasing hormone neurons in mice. Biol Reprod. 2011 Nov;85(5):987-95.

36 Sun J, Chu Z, Moenter SM. Diurnal in vivo and rapid in vitro effects of estradiol on voltage-gated calcium channels in gonadotropinreleasing hormone neurons. J Neurosci. 2010 Mar;30(11):3912-23.

37 Zhang C, Bosch MA, Rick EA, Kelly MJ, Rønnekleiv OK. 17Beta-estradiol regulation of Ttype calcium channels in gonadotropin-releasing hormone neurons. J Neurosci. 2009 Aug;29(34):10552-62.

38 Chu Z, Takagi H, Moenter SM. Hyperpolarization-activated currents in gonadotropinreleasing hormone $(\mathrm{GnRH})$ neurons contribute to intrinsic excitability and are regulated by gonadal steroid feedback. J Neurosci. 2010 Oct;30(40):13373-83.

39 Christian CA, Pielecka-Fortuna J, Moenter SM. Estradiol suppresses glutamatergic transmission to gonadotropin-releasing hormone neurons in a model of negative feedback in mice. Biol Reprod. 2009 Jun;80(6):1128-35.

40 Christian CA, Moenter SM. Estradiol induces diurnal shifts in GABA transmission to gonadotropin-releasing hormone neurons to provide a neural signal for ovulation. J Neurosci. 2007 Feb;27(8):1913-21.

41 Adams C, Stroberg W, DeFazio RA, Schnell S, Moenter SM. Gonadotropin-releasing hormone $(\mathrm{GnRH})$ neuron excitability is regulated by estradiol feedback and kisspeptin. J Neurosci. 2018 Jan;38(5):1249-63.

42 Adams C, DeFazio RA, Christian CA, Milescu LS, Schnell S, Moenter SM. Changes in both neuron intrinsic properties and neurotransmission are needed to drive the increase in GnRH neuron firing rate during estradiolpositive feedback. J Neurosci. 2019 Mar; 39(11):2091-101.

43 Kuiper GG, Enmark E, Pelto-Huikko M, Nilsson S, Gustafsson JA. Cloning of a novel receptor expressed in rat prostate and ovary. Proc Natl Acad Sci USA. 1996 Jun;93(12): 5925-30.

44 Tremblay GB, Tremblay A, Copeland NG, Gilbert DJ, Jenkins NA, Labrie F, et al. Cloning, chromosomal localization, and functional analysis of the murine estrogen receptor $\beta$. Mol Endocrinol. 1997 Mar;11(3):353-65. 
45 Koike S, Sakai M, Muramatsu M. Molecular cloning and characterization of rat estrogen receptor cDNA. Nucleic Acids Res. 1987 Mar; 15(6):2499-513.

46 Micevych PE, Mermelstein PG, Sinchak K. Estradiol membrane-initiated signaling in the brain mediates reproduction. Trends Neurosci. 2017 Nov;40(11):654-66.

47 Micevych PE, Kelly MJ. Membrane estrogen receptor regulation of hypothalamic function. Neuroendocrinology. 2012;96(2):103-10.

48 Olde B, Leeb-Lundberg LM. GPR30/GPER1: searching for a role in estrogen physiology. Trends Endocrinol Metab. 2009 Oct;20(8): 409-16.

49 Mangelsdorf DJ, Thummel C, Beato M, Herrlich P, Schütz G, Umesono K, et al. The nuclear receptor superfamily: the second decade. Cell. 1995 Dec;83(6):835-9.

50 Björnström L, Sjöberg M. Mechanisms of estrogen receptor signaling: convergence of genomic and nongenomic actions on target genes. Mol Endocrinol. 2005 Apr;19(4):83342.

51 Ayaz G, Yasar P, Olgun CE, Karakaya B, Kars G, Razizadeh N, et al. Dynamic transcriptional events mediated by estrogen receptor alpha. Front Biosci. 2019 Jan;24(2):245-76.

52 Qiu J, Rønnekleiv OK, Kelly MJ. Modulation of hypothalamic neuronal activity through a novel G-protein-coupled estrogen membrane receptor. Steroids. 2008 Oct;73(9-10):985-91.

53 Chu Z, Andrade J, Shupnik MA, Moenter SM. Differential regulation of gonadotropin-releasing hormone neuron activity and membrane properties by acutely applied estradiol: dependence on dose and estrogen receptor subtype. J Neurosci. 2009 Apr;29(17):561627.

54 Mhyre AJ, Dorsa DM. Estrogen activates rapid signaling in the brain: role of estrogen receptor $\alpha$ and estrogen receptor $\beta$ in neurons and glia. Neuroscience. 2006;138(3):851-8.

55 Moss RL, Gu Q, Wong M. Estrogen: nontranscriptional signaling pathway. Recent Prog Horm Res. 1997;52:33-68.

56 Kelly MJ, Qiu J. Estrogen signaling in hypothalamic circuits controlling reproduction. Brain Res. 2010 Dec;1364:44-52.

57 Christian CA, Glidewell-Kenney C, Jameson JL, Moenter SM. Classical estrogen receptor a signaling mediates negative and positive feedback on gonadotropin-releasing hormone neuron firing. Endocrinology. 2008 Nov; 149(11):5328-34.

58 Glidewell-Kenney C, Hurley LA, Pfaff L, Weiss J, Levine JE, Jameson JL. Nonclassical estrogen receptor alpha signaling mediates negative feedback in the female mouse reproductive axis. Proc Natl Acad Sci USA. 2007 May;104(19):8173-7.

59 Lubahn DB, Moyer JS, Golding TS, Couse JF, Korach KS, Smithies O. Alteration of reproductive function but not prenatal sexual development after insertional disruption of the mouse estrogen receptor gene. Proc Natl Acad Sci USA. 1993 Dec;90(23):11162-6.
60 Krege JH, Hodgin JB, Couse JF, Enmark E, Warner M, Mahler JF, et al. Generation and reproductive phenotypes of mice lacking estrogen receptor beta. Proc Natl Acad Sci USA. 1998 Dec;95(26):15677-82.

61 Wersinger SR, Haisenleder DJ, Lubahn DB, Rissman EF. Steroid feedback on gonadotropin release and pituitary gonadotropin subunit mRNA in mice lacking a functional estrogen receptor a. Endocrine. 1999 Oct;11(2): $137-43$.

62 Wintermantel TM, Campbell RE, Porteous R, Bock D, Gröne HJ, Todman MG, et al. Definition of estrogen receptor pathway critical for estrogen positive feedback to gonadotropinreleasing hormone neurons and fertility. Neuron. 2006 Oct;52(2):271-80.

63 Noel SD, Keen KL, Baumann DI, Filardo EJ, Terasawa E. Involvement of $\mathrm{G}$ protein-coupled receptor 30 (GPR30) in rapid action of estrogen in primate LHRH neurons. Mol Endocrinol. 2009 Mar;23(3):349-59.

64 Hrabovszky E, Steinhauser A, Barabás K, Shughrue PJ, Petersen SL, Merchenthaler I, et al. Estrogen receptor-beta immunoreactivity in luteinizing hormone-releasing hormone neurons of the rat brain. Endocrinology. 2001 Jul;142(7):3261-4.

65 de Roux N, Genin E, Carel JC, Matsuda F, Chaussain JL, Milgrom E. Hypogonadotropic hypogonadism due to loss of function of the KiSS1-derived peptide receptor GPR54. Proc Natl Acad Sci USA. 2003 Sep;100(19):109726.

66 Seminara SB, Messager S, Chatzidaki EE, Thresher RR, Acierno JS Jr, Shagoury JK, et al. The GPR54 gene as a regulator of puberty. N Engl J Med. 2003 Oct;349(17):1614-27.

67 d'Anglemont de Tassigny X, Fagg LA, Dixon JP, Day K, Leitch HG, Hendrick AG, et al. Hypogonadotropic hypogonadism in mice lacking a functional Kiss1 gene. Proc Natl Acad Sci USA. 2007 Jun;104(25):10714-9.

68 Ohtaki T, Shintani Y, Honda S, Matsumoto H, Hori A, Kanehashi K, et al. Metastasis suppressor gene KiSS- 1 encodes peptide ligand of a G-protein-coupled receptor. Nature. 2001 May;411(6837):613-7.

69 Bhattacharya M, Babwah AV. Kisspeptin: beyond the brain. Endocrinology. 2015 Apr; 156(4):1218-27.

70 Smith JT, Popa SM, Clifton DK, Hoffman GE, Steiner RA. Kiss1 neurons in the forebrain as central processors for generating the preovulatory luteinizing hormone surge. J Neurosci. 2006 Jun;26(25):6687-94.

71 Cravo RM, Margatho LO, Osborne-Lawrence S, Donato J Jr, Atkin S, Bookout AL, et al. Characterization of Kiss1 neurons using transgenic mouse models. Neuroscience. 2011 Jan;173:37-56.

72 Roseweir AK, Kauffman AS, Smith JT, Guerriero KA, Morgan K, Pielecka-Fortuna J, et al. Discovery of potent kisspeptin antagonists delineate physiological mechanisms of gonadotropin regulation. J Neurosci. 2009 Mar; 29(12):3920-9.
73 Smith JT, Cunningham MJ, Rissman EF, Clifton DK, Steiner RA. Regulation of Kiss1 gene expression in the brain of the female mouse. Endocrinology. 2005 Sep;146(9):3686-92.

74 Smith JT, Dungan HM, Stoll EA, Gottsch ML, Braun RE, Eacker SM, et al. Differential regulation of KiSS-1 mRNA expression by sex steroids in the brain of the male mouse. Endocrinology. 2005 Jul;146(7):2976-84.

75 Smith JT, Coolen LM, Kriegsfeld LJ, Sari IP, Jaafarzadehshirazi MR, Maltby M, et al. Variation in kisspeptin and RFamide-related peptide (RFRP) expression and terminal connections to gonadotropin-releasing hormone neurons in the brain: a novel medium for seasonal breeding in the sheep. Endocrinology. 2008 Nov; 149(11):5770-82.

76 Ramaswamy S, Guerriero KA, Gibbs RB, Plant TM. Structural interactions between kisspeptin and GnRH neurons in the mediobasal hypothalamus of the male rhesus monkey (Macaca mulatta) as revealed by double immunofluorescence and confocal microscopy. Endocrinology. 2008 Sep;149(9):4387-95.

77 Lehman MN, Coolen LM, Goodman RL. Minireview: kisspeptin/neurokinin B/dynorphin (KNDy) cells of the arcuate nucleus: a central node in the control of gonadotropinreleasing hormone secretion. Endocrinology. 2010 Aug;151(8):3479-89.

78 Clarkson J, Herbison AE. Postnatal development of kisspeptin neurons in mouse hypothalamus; sexual dimorphism and projections to gonadotropin-releasing hormone neurons. Endocrinology. 2006 Dec;147(12):5817-25.

79 Yeo SH, Herbison AE. Projections of arcuate nucleus and rostral periventricular kisspeptin neurons in the adult female mouse brain. Endocrinology. 2011 Jun;152(6):2387-99.

80 Ciofi P, Leroy D, Tramu G. Sexual dimorphism in the organization of the rat hypothalamic infundibular area. Neuroscience. 2006 Sep;141(4):1731-45.

81 Herbison AE, de Tassigny X, Doran J, Colledge WH. Distribution and postnatal development of Gpr54 gene expression in mouse brain and gonadotropin-releasing hormone neurons. Endocrinology. 2010 Jan; 151(1):312-21.

82 Lee DK, Nguyen T, O'Neill GP, Cheng R, Liu $\mathrm{Y}$, Howard AD, et al. Discovery of a receptor related to the galanin receptors. FEBS Lett. 1999 Mar;446(1):103-7.

83 Pielecka-Fortuna J, Chu Z, Moenter SM. Kisspeptin acts directly and indirectly to increase gonadotropin-releasing hormone neuron activity and its effects are modulated by estradiol. Endocrinology. 2008 Apr;149(4):197986.

84 Han SK, Gottsch ML, Lee KJ, Popa SM, Smith JT, Jakawich SK, et al. Activation of gonadotropin-releasing hormone neurons by kisspeptin as a neuroendocrine switch for the onset of puberty. J Neurosci. 2005 Dec;25(49): 11349-56. 
85 Messager S, Chatzidaki EE, Ma D, Hendrick AG, Zahn D, Dixon J, et al. Kisspeptin directly stimulates gonadotropin-releasing hormone release via $\mathrm{G}$ protein-coupled receptor 54. Proc Natl Acad Sci USA. 2005 Feb;102(5): $1761-6$.

86 Kinoshita M, Tsukamura H, Adachi S, Matsui $\mathrm{H}$, Uenoyama $\mathrm{Y}$, Iwata $\mathrm{K}$, et al. Involvement of central metastin in the regulation of preovulatory luteinizing hormone surge and estrous cyclicity in female rats. Endocrinology. 2005 Oct;146(10):4431-6.

87 Kirilov M, Clarkson J, Liu X, Roa J, Campos P, Porteous R, et al. Dependence of fertility on kisspeptin-Gpr54 signaling at the GnRH neuron. Nat Commun. 2013;4(1):2492.

88 Oakley AE, Clifton DK, Steiner RA. Kisspeptin signaling in the brain. Endocr Rev. 2009 Oct;30(6):713-43.

89 Plant TM, Krey LC, Moossy J, McCormack JT, Hess DL, Knobil E. The arcuate nucleus and the control of gonadotropin and prolactin secretion in the female rhesus monkey (Macaca mulatta). Endocrinology. 1978 Jan; 102(1):52-62.

90 Soper BD, Weick RF. Hypothalamic and extrahypothalamic mediation of pulsatile discharges of luteinizing hormone in the ovariectomized rat. Endocrinology. 1980 Jan; 106(1):348-55

91 Mori Y, Nishihara M, Tanaka T, Shimizu T, Yamaguchi M, Takeuchi Y, et al. Chronic recording of electrophysiological manifestation of the hypothalamic gonadotropin-releasing hormone pulse generator activity in the goat. Neuroendocrinology. 1991 Apr;53(4):392-5.

92 Kawakami M, Uemura T, Hayashi R. Electrophysiological correlates of pulsatile gonadotropin release in rats. Neuroendocrinology. 1982;35(1):63-7.

93 Wilson RC, Kesner JS, Kaufman JM, Uemura T, Akema T, Knobil E. Central electrophysiologic correlates of pulsatile luteinizing hormone secretion in the rhesus monkey. Neuroendocrinology. 1984 Sep;39(3):256-60.

94 Martin GB, Thiéry JC. Hypothalamic multiunit activity and LH secretion in conscious sheep. Exp Brain Res. 1987;67(3):469-78.

95 Clarkson J, Han SY, Piet R, McLennan T, Kane GM, Ng J, et al. Definition of the hypothalamic $\mathrm{GnRH}$ pulse generator in mice. Proc NatlAcadSciUSA.2017Nov;114(47):E1021623.

96 Navarro VM, Castellano JM, McConkey SM, Pineda R, Ruiz-Pino F, Pinilla L, et al. Interactions between kisspeptin and neurokinin $\mathrm{B}$ in the control of $\mathrm{GnRH}$ secretion in the female rat. Am J Physiol Endocrinol Metab. 2011 Jan; 300(1):E202-10.

97 Navarro VM, Gottsch ML, Chavkin C, Okamura H, Clifton DK, Steiner RA. Regulation of gonadotropin-releasing hormone secretion by kisspeptin/dynorphin/neurokinin B neurons in the arcuate nucleus of the mouse. J Neurosci. 2009 Sep;29(38):11859-66.
98 Wakabayashi Y, Nakada T, Murata K, Ohkura S, Mogi K, Navarro VM, et al. Neurokinin $\mathrm{B}$ and dynorphin $\mathrm{A}$ in kisspeptin neurons of the arcuate nucleus participate in generation of periodic oscillation of neural activity driving pulsatile gonadotropin-releasing hormone secretion in the goat. J Neurosci. 2010 Feb;30(8):3124-32.

99 Goodman RL, Hileman SM, Nestor CC, Porter KL, Connors JM, Hardy SL, et al. Kisspeptin, neurokinin $\mathrm{B}$, and dynorphin act in the arcuate nucleus to control activity of the GnRH pulse generator in ewes. Endocrinology. 2013 Nov;154(11):4259-69.

100 Ruka KA, Burger LL, Moenter SM. Regulation of arcuate neurons coexpressing kisspeptin, neurokinin $\mathrm{B}$, and dynorphin by modulators of neurokinin 3 and $\kappa$-opioid receptors in adult male mice. Endocrinology. 2013 Aug;154(8):2761-71.

101 de Croft S, Piet R, Mayer C, Mai O, Boehm U, Herbison AE. Spontaneous kisspeptin neuron firing in the adult mouse reveals marked sex and brain region differences but no support for a direct role in negative feedback. Endocrinology. 2012 Nov; 153(11):5384-93.

102 Qiu J, Nestor CC, Zhang C, Padilla SL, Palmiter RD, Kelly MJ, et al. High-frequency stimulation-induced peptide release synchronizes arcuate kisspeptin neurons and excites GnRH neurons. eLife. 2016 Aug; 5:e16246.

103 Krajewski SJ, Anderson MJ, Iles-Shih L, Chen KJ, Urbanski HF, Rance NE. Morphologic evidence that neurokinin B modulates gonadotropin-releasing hormone secretion via neurokinin 3 receptors in the rat median eminence. J Comp Neurol. 2005 Aug; 489(3):372-86

104 Vanacker C, Moya MR, DeFazio RA, Johnson ML, Moenter SM. Long-term recordings of arcuate nucleus kisspeptin neurons reveal patterned activity that is modulated by gonadal steroids in male mice. Endocrinology. 2017 Oct;158(10):3553-64.

105 Navarro VM, Gottsch ML, Wu M, GarcíaGaliano D, Hobbs SJ, Bosch MA, et al. Regulation of NKB pathways and their roles in the control of Kiss1 neurons in the arcuate nucleus of the male mouse. Endocrinology. 2011 Nov;152(11):4265-75.

106 Han SY, McLennan T, Czieselsky K, Herbison AE. Selective optogenetic activation of arcuate kisspeptin neurons generates pulsatile luteinizing hormone secretion. Proc Natl Acad Sci USA. 2015 Oct;112(42): 13109-14.

107 Han SY, Kane G, Cheong I, Herbison AE. Characterization of GnRH Pulse Generator Activity in Male Mice Using GCaMP Fiber Photometry. Endocrinology. 2019 Mar; 160(3):557-67

108 Kumar D, Freese M, Drexler D, HermansBorgmeyer I, Marquardt A, Boehm U. Murine arcuate nucleus kisspeptin neurons communicate with GnRH neurons in utero. J Neurosci. 2014 Mar;34(10):3756-66.
109 Mayer C, Boehm U. Female reproductive maturation in the absence of kisspeptin/ GPR54 signaling. Nat Neurosci. 2011 Jun; 14(6):704-10.

110 Padilla SL, Perez JG, Ben-Hamo M, Johnson CW, Sanchez RE, Bussi IL, et al. Kisspeptin neurons in the arcuate nucleus of the hypothalamus orchestrate circadian rhythms and metabolism. Curr Biol. 2019 Feb;29(4): 592-604.e4.

111 Ruka KA, Burger LL, Moenter SM. Both estrogen and androgen modify the response to activation of neurokinin- 3 and $\kappa$-opioid receptors in arcuate kisspeptin neurons from male mice. Endocrinology. 2016 Feb; 157(2):752-63.

112 Wang L, Burger LL, Greenwald-Yarnell ML Myers MG Jr, Moenter SM. Glutamatergic transmission to hypothalamic kisspeptin neurons is differentially regulated by estradiol through estrogen receptor $\alpha$ in adult female mice. J Neurosci. 2018 Jan;38(5):106172.

113 Phumsatitpong CM. Corticotropin-releasing hormone (CRH) has no effect on arcuate kisspeptin neuron firing activity in female mice. Soc Neurosci. 2019;673:13.

114 DeFazio RA, Elias CF, Moenter SM. GABAergic transmission to kisspeptin neurons is differentially regulated by time of day and estradiol in female mice. J Neurosci. 2014 Dec;34(49):16296-308.

115 Greenwald-Yarnell ML, Marsh C, Allison MB, Patterson CM, Kasper C, MacKenzie A, et al. ERa in Tac2 neurons regulates puberty onset in female mice. Endocrinology. 2016 Apr;157(4):1555-65.

116 Mayer C, Acosta-Martinez M, Dubois SL, Wolfe A, Radovick S, Boehm U, et al. Timing and completion of puberty in female mice depend on estrogen receptor alphasignaling in kisspeptin neurons. Proc Natl Acad Sci USA. 2010 Dec;107(52):22693-8.

117 Dubois SL, Acosta-Martínez M, DeJoseph MR, Wolfe A, Radovick S, Boehm U, et al. Positive, but not negative feedback actions of estradiol in adult female mice require estrogen receptor a in kisspeptin neurons. Endocrinology. 2015 Mar;156(3):1111-20.

118 Semaan SJ, Murray EK, Poling MC, Dhamija S, Forger NG, Kauffman AS. BAX-dependent and BAX-independent regulation of Kiss1 neuron development in mice. Endocrinology. 2010 Dec;151(12):5807-17.

119 Wang L, Vanacker C, Burger LL, Barnes T, Shah YM, Myers MG, et al. Genetic dissection of the different roles of hypothalamic kisspeptin neurons in regulating female reproduction. Elife. 2019 Apr;8:e43999.

120 Czieselsky K, Prescott M, Porteous R, Campos P, Clarkson J, Steyn FJ, et al. Pulse and surge profiles of luteinizing hormone secretion in the mouse. Endocrinology. 2016 Dec;157(12):4794-802. 
121 Watson RE Jr, Langub MC Jr, Engle MG, Maley BE. Estrogen-receptive neurons in the anteroventral periventricular nucleus are synaptic targets of the suprachiasmatic nucleus and peri-suprachiasmatic region. Brain Res. 1995 Aug;689(2):254-64.

122 Brock O, De Mees C, Bakker J. Hypothalamic expression of oestrogen receptor $\alpha$ and androgen receptor is sex-, age- and regiondependent in mice. J Neuroendocrinol. 2015 Apr;27(4):264-76.

123 Gu GB, Simerly RB. Projections of the sexually dimorphic anteroventral periventricular nucleus in the female rat. J Comp Neurol. 1997 Jul;384(1):142-64.

124 Le WW, Berghorn KA, Rassnick S, Hoffman GE. Periventricular preoptic area neurons coactivated with luteinizing hormone ( $\mathrm{LH}$ )releasing hormone (LHRH) neurons at the time of the LH surge are LHRH afferents. Endocrinology. 1999 Jan;140(1):510-9.

125 Wiegand SJ, Terasawa E. Discrete lesions reveal functional heterogeneity of suprachiasmatic structures in regulation of gonadotropin secretion in the female rat. Neuroendocrinology. 1982 Jun;34(6):395-404.

126 Wiegand SJ, Terasawa E, Bridson WE, Goy RW. Effects of discrete lesions of preoptic and suprachiasmatic structures in the female rat. Alterations in the feedback regulation of gonadotropin secretion. Neuroendocrinology. 1980 Aug;31(2):147-57.

127 Wiegand SJ, Terasawa E, Bridson WE. Persistent estrus and blockade of progesteroneinduced LH release follows lesions which do not damage the suprachiasmatic nucleus. Endocrinology. 1978 May;102(5):1645-8.

128 Kauffman AS, Gottsch ML, Roa J, Byquist AC, Crown A, Clifton DK, et al. Sexual differentiation of Kiss1 gene expression in the brain of the rat. Endocrinology. 2007 Apr; 148(4):1774-83.

129 Clarkson J, d'Anglemont de Tassigny X, Moreno AS, Colledge WH, Herbison AE. Kisspeptin-GPR54 signaling is essential for preovulatory gonadotropin-releasing hormone neuron activation and the luteinizing hormone surge. J Neurosci. 2008 Aug; 28(35):8691-7.

130 Robertson JL, Clifton DK, de la Iglesia HO, Steiner RA, Kauffman AS. Circadian regulation of Kiss1 neurons: implications for timing the preovulatory gonadotropin-releasing hormone/luteinizing hormone surge. Endocrinology. 2009 Aug;150(8):3664-71.

131 Kumar D, Candlish M, Periasamy V, Avcu N, Mayer C, Boehm U. Specialized subpopulations of kisspeptin neurons communicate with GnRH neurons in female mice. Endocrinology. 2015 Jan;156(1):32-8.

132 Clarkson J, Herbison AE. Dual phenotype kisspeptin-dopamine neurones of the rostral periventricular area of the third ventricle project to gonadotrophin-releasing hormone neurones. J Neuroendocrinol. 2011 Apr;23(4):293-301.
133 DeFazio RA, Heger S, Ojeda SR, Moenter SM. Activation of A-type gamma-aminobutyric acid receptors excites gonadotropinreleasing hormone neurons. Mol Endocrinol. 2002 Dec;16(12):2872-91.

134 Kuehl-Kovarik MC, Pouliot WA, Halterman GL, Handa RJ, Dudek FE, Partin KM. Episodic bursting activity and response to excitatory amino acids in acutely dissociated gonadotropin-releasing hormone neurons genetically targeted with green fluorescent protein. J Neurosci. 2002 Mar;22(6): 2313-22.

135 Stephens SBZ, Rouse ML, Tolson KP, Liaw RB, Parra RA, Chahal N, et al. Effects of selective deletion of tyrosine hydroxylase from kisspeptin cells on puberty and reproduction in male and female mice. eNeuro. 2017 Jun;4(3):pii:ENEURO.0150-17.2017.

136 Piet R, Kalil B, McLennan T, Porteous R, Czieselsky K, Herbison AE. Dominant neuropeptide cotransmission in kisspeptinGABA regulation of $\mathrm{GnRH}$ neuron firing driving ovulation. J Neurosci. 2018 Jul; 38(28):6310-22.

137 Wang L, DeFazio RA, Moenter SM. Excitability and burst generation of AVPV kisspeptin neurons are regulated by the estrous cycle via multiple conductances modulated by estradiol action. eNeuro. 2016 Jun; 3(3):e0094-16.

138 Piet R, Boehm U, Herbison AE. Estrous cycle plasticity in the hyperpolarization-activated current ih is mediated by circulating $17 \beta$-estradiol in preoptic area kisspeptin neurons. J Neurosci. 2013 Jun;33(26): 10828-39.

139 Zhang C, Bosch MA, Qiu J, Rønnekleiv OK, Kelly MJ. 17 $\beta$-Estradiol increases persistent $\mathrm{Na}(+)$ current and excitability of AVPV/ PeN Kiss1 neurons in female mice. Mol Endocrinol. 2015 Apr;29(4):518-27.

140 Zhang C, Tonsfeldt KJ, Qiu J, Bosch MA, Kobayashi K, Steiner RA, et al. Molecular mechanisms that drive estradiol-dependent burst firing of Kiss1 neurons in the rostral periventricular preoptic area. Am J Physiol Endocrinol Metab. 2013 Dec; 305(11):E1384-97.

141 Suzuki S, Rogawski MA. T-type calcium channels mediate the transition between tonic and phasic firing in thalamic neurons. Proc Natl Acad Sci USA. 1989 Sep;86(18):7228-32.

142 Khaliq ZM, Bean BP. Pacemaking in dopaminergic ventral tegmental area neurons: depolarizing drive from background and voltage-dependent sodium conductances. J Neurosci. 2010 May;30(21):7401-13.

143 Krahe R, Gabbiani F. Burst firing in sensory systems. Nat Rev Neurosci. 2004 Jan;5(1): $13-23$.
144 Porteous R, Herbison AE. Genetic deletion of Esr1 in the mouse preoptic area disrupts the LH surge and estrous cyclicity. Endocrinology. 2019 Aug;160(8):1821-9.

145 Cheong RY, Czieselsky K, Porteous R, Herbison AE. Expression of ESR1 in glutamatergic and GABAergic neurons is essential for normal puberty onset, estrogen feedback, and fertility in female mice. J Neurosci. 2015 Oct;35(43):14533-43.

146 Meng C, Zhou J, Papaneri A, Peddada T, Xu $\mathrm{K}$, Cui G. Spectrally resolved fiber photometry for multi-component analysis of brain circuits. Neuron. 2018 May;98(4):707-717. e4.

147 Sych Y, Chernysheva M, Sumanovski LT, Helmchen F. High-density multi-fiber photometry for studying large-scale brain circuit dynamics. Nat Methods. 2019 Jun; 16(6):553-60.

148 León S, Barroso A, Vázquez MJ, GarcíaGaliano D, Manfredi-Lozano M, Ruiz-Pino $\mathrm{F}$, et al. Direct actions of kisspeptins on GnRH neurons permit attainment of fertility but are insufficient to fully preserve gonadotropic axis activity. Sci Rep. 2016 Jan;6: 19206.

149 Pielecka-Fortuna J, Moenter SM. Kisspeptin increases $\gamma$-aminobutyric acidergic and glutamatergic transmission directly to gonadotropin-releasing hormone neurons in an estradiol-dependent manner. Endocrinology. 2010 Jan;151(1):291-300.

150 Chachlaki K, Garthwaite J, Prevot V. The gentle art of saying NO: how nitric oxide gets things done in the hypothalamus. Nat Rev Endocrinol. 2017 Sep;13(9):521-35.

151 Clasadonte J, Poulain P, Beauvillain JC, Prevot V. Activation of neuronal nitric oxide release inhibits spontaneous firing in adult gonadotropin-releasing hormone neurons: a possible local synchronizing signal. Endocrinology. 2008 Feb;149(2):587-96.

152 Hanchate NK, Parkash J, Bellefontaine N, Mazur D, Colledge WH, d'Anglemont de Tassigny X, et al. Kisspeptin-GPR54 signaling in mouse NO-synthesizing neurons participates in the hypothalamic control of ovulation. J Neurosci. 2012 Jan;32(3):93245.

153 Moffitt JR, Bambah-Mukku D, Eichhorn SW, Vaughn E, Shekhar K, Perez JD, et al. Molecular, spatial, and functional singlecell profiling of the hypothalamic preoptic region. Science. 2018 Nov 362(6416):eaau5324.

154 Campbell JN, Macosko EZ, Fenselau H, Pers TH, Lyubetskaya A, Tenen D, et al. A molecular census of arcuate hypothalamus and median eminence cell types. Nat Neurosci. 2017 Mar;20(3):484-96. 